\title{
EFFECTIVENESS OF CAPITAL MARKET DERIVATIVES IN HOUSING DELIVERY OF NIGERIA EMERGING MARKET
}

\author{
Bernard Adjekophori \\ Department of Estate Management and Valuation, Auchi Polytechnic, Auchi.Edo State. Nigeria \\ benejis@gmail.com \\ Sulaimon Olanrewaju Adebiyi \\ Department of Business Administration, Fountain University Osogbo, Osun state. Nigeria \\ lanre18april@gmail.com
}

\begin{abstract}
The capital market is unarguably the most robust institution in any economy notable for mobilizing the necessary fund for financing long-term productive project. It controls relatively large amounts of capital and represent the largest institutional providing long-term credits for capital project like real estate that requires huge capital outlay. This study therefore, attempts an investigation into the effectiveness of capital market derivatives in housing delivery in Lagos. An empirical survey research was conducted in Lagos, using a random sampling technique with a structured questionnaire to collect data from 147 respondents comprising 89 stockbrokers and 58 real estate developers in Lagos mega-city. Data collected were analyzed with SPSS using descriptive and inferential statistics. The result revealed that $56.7 \%$ of the observed variations in housing delivery $\left(R^{2}=0.567 ; p<0.05\right)$ is explained by capital market derivatives, which suggests that, proper utilization of capital market derivatives will enhance and improve housing delivery in Nigeria. However, this is not been adequately used by developers of real estate projects in the study. Thus, the study recommends amongst other remedial steps that a synergetic effort should be created between the capital market and real estate developers which will enhance effective housing delivery, the development of people and the Nation.
\end{abstract}

\section{Keywords}

Capital market derivatives; housing delivery; finance; emerging market; real estate

\section{JEL Classification}

G12

\section{Introduction}

Housing and its finance are topics that are of great interest/concern in any nationdeveloped, developing or emerging market. Investment in housing according to Buckley (1989) typically amounts to $3 \%$ to $8 \%$ of GDP and up to $15 \%$ to $20 \%$ of gross fixed capital formation. Studies have asserted that finance is the pillar, pivot, key, cornerstone and the most crucial element in housing investment and the availability of which determines access to other key inputs of land, labour, materials and infrastructure (Nubi, 2002; Boonybancha; 2002; Ogedengbe \& Adesopo, 2003).

The financing of housing is a key element of any housing policy. In general, two objectives should be taken into account in order to make financing options viable and sustainable. Thus, the options should offer profitability to market participants, otherwise, it will not be feasible to attract investment, particularly private investment to the housing sector; and secondly, they should be adapted to the potential borrowers' ability to pay, otherwise, the low-income population will be marginalized from market operations. 
Therefore, the provision of affordable housing at scale remains a challenge to most countries particularly those in developing country like Nigeria. It has become increasingly glaring that most urban population according to Nubi (2000), live in dehumanizing housing environment, while those that have access to average housing do so at abnormal cost. Housing is essentially necessary to the extent that in some countries is equated with human right (Nevova, 2010). Habitable housing according to Mabogunje (1989) discourage anti-social behavior, promotes healthy living, efficiency, and general well-being of the populace. Housing does not only serve as an asset to individual and Nation, it also provides man with cover and security (Poole, 2003, Alhashimi \& Dwyer, 2004).

Traditionally, real estate companies, investors and developers in Nigeria obtain financing through bank loans. As Nigeria is a bank-oriented financial system in which the banking system provides funds for investments in contrast to market-oriented economies like the U.S. - with investment to a large extent being financed through the financial markets by various actors; such as private investors and corporations with excess capital. Comparably in emerging economies including Nigeria few companies fund themselves through the capital market (Berggren and Silver, 2011).

To achieve a successful housing finance and ensure continuous flow of funds, the government set up three main schemes: voluntary scheme, mandatory scheme and government financial transfer to housing (Onokube, 2007). As a market for the provision of long-term fund the capital market plays a major role in the administration of these schemes. The capital market is responsible for long-term capital formation and this makes it a good engine that can drive any economy to positive growth and development. The money market however, only provides support to the capital market in the provision of the necessary liquid capital to compliment the total fixed capital. Therefore, the capital market is a good avenue for mobilizing huge and long-term capital required for funding housing development and investments. There exist various vehicles/devices available in the capital market for funding real estate projects which include but not limited to Property bonds, Real estate investment trust (REIT), property unit trusts, loan stock and debenture stocks (Torty, 2002).

Property bond is an available device for small investors that cannot achieve their dream of investing in prime properties due to inadequate fund. (Emoh \& Nwachukwu, 2011). Such investor will only purchase few units in a fund and invest in prime properties in prime location and cities that have the capacity and potential to grow capital. The global universe of real estate companies has expanded dramatically over the past decade due to the very strong performance of the sector, ongoing equity issuance and a proliferation of REIT vehicles across the globe, which has attracted capital into the sector. REITs generally allow participants to invest in a professionally-managed portfolio of real estate properties and their business activities are usually restricted to generation of property rental income. The introduction of REITs in the US and other developed economies has created a remarkable positive change in real estate finance. This is not yet the case in Nigeria, and other emerging nations with REITs.

There is no doubt that finance is an important factor in real estate development. Lack of long-term finance to develop mass housing is a major hindrance to housing for all. After 54 years of Nigeria independence, a vibrant mortgage market is yet to be developed (Ojo, 2009; Yinka, 2011). The existing mortgage scheme that should provide cheaper housing development loan is grossly incapable of satisfying the needs of the populace. Kim (1997) and Quigley (2000) observed that, where there is no virile financing structure for housing, a market-based housing delivery system will persist.

There are enormous benefits and opportunities to developed economies from the aforementioned capital market products, this study wonders if emerging nations 
especially Nigeria is also threading this path towards an efficient and continuous housing finance system. The thrust of this study therefore, is to examine the effectiveness of capital market derivatives in housing finance in emerging markets with particularly reference to Nigeria.

\subsection{Statement of the problem}

One of the major engine of economic growth and development of a nation is its capital market. It impacts positively on the economy by providing financial resources through its intermediation process for the financing of long term projects. Hence without an efficient capital market, the economy may be starved of the required longterm fund for sustainable growth.

One may perhaps be tempted to ask why emphasis is being placed on finance and especially housing finance. First and foremost, of all man's basic needs, housing arguably, constitutes and indeed poses the greatest challenge. Secondly, a vigorous and buoyant housing sector is an indication of a strong program of national investment and is indeed the foundation of and the first step to future economic growth and social development (Ajanlekoko, 2001, Folorunsho, Khan \& Olowoyo, 2012).

Experts have estimated the housing deficit in Nigeria as at 2005 to be at between seventeen million (Omirin \& Nubi, 2007; Adejumo, 2008); and that a good percentage of Nigerian especially the urban dwellers either live in substandard rented apartment or homeless. An estimation of between 42 trillion to 56 trillion naira would be needed to close the deficit gap with an estimate of average cost of $\$ 4.9$ million ( $\$ 14000$ ) (rate of US\$1= $\$ 350$ ) per housing unit with the exclusion of land value that are very high in the cities. This is almost beyond individual and banks financing option. Access to housing finance is thus imperative in the acquisition of housing, but this has always eluded low-income earners a great deal. The implication therefore is that social and economic challenges associated with housing will persist in Nigeria if this is not address (Adedeji \& Olotuah, 2012). Finance is an essential ingredient of modern day real estate development and most large scale development would not assume their present scale without substantial credit (Ogedengbe \& Adesopo, 2003). Thus the capital market presents a viable source for this financial option.

The Nigeria bond and REITs market is still at its infancy therefore still underdeveloped as real estate developer/investors and companies traditionally obtain debt through bank loans. Until a few years ago, was REITs introduced to Nigeria capital market with Skye Shelter Funds and Union Homes Real Estate taking the lead in 2007 and 2008 respectively. The positive impact of the successful developed market economies REITs and bonds are not seeming to be replicated in Nigeria and other emerging nations. Furthermore, the role of the capital marker vis-à-vis its products in financing housing and economic development has been subjected to several criticisms (Oyejide, 1994; Nyong, 1998; Osaze, 2000; Sule \& Momoh, 2009; Ewah, Esang \& Bassey, 2009; Idowu, Osagie \& Nubi, 2011). These various concern and controversies produced mixed result that some researchers argued for positive correlation, others negative correlation and some of the studies are theoretical and qualitative even while other could not authenticate their conclusion with empirical evident.

From the foregoing, this paper empirically investigates the challenges and prospects, and establishes the extent to which these capital market derivatives can efficiently and effectively serve as a viable alternative to financing real estate in an emerging economy. 


\subsection{Aim and Objectives}

The cardinal goal of this study is to examine the effectiveness of capital market derivatives in housing delivery in Nigeria emerging market. In achieving this aim, the specific objectives are to:

(i) identify the capital market derivatives that are available for real estate development in the study area.

(ii) assess the extent of use of these derivatives by real estate developers and investors in the study area.

(iii) examine developers/investors demand preference for financing real estate with capital market products in the study area.

(iv) identify the challenges hampering the use of capital market products in financing real estate investment in the study area.

\subsection{Research Questions}

In pursuance of the above stated objectives, the study will attempt to answer the following questions.

(i) What are the major capital market derivatives available for real estate development in the study area?

(ii) To what extent are these derivatives used for real estate financing in the study area?

(iii) What is developers/investors demand preference for financing real estate with capital market products in the study area?

(iv) What are the challenges militating against the use of capital market derivatives financing for real estate investment in the study area?

\subsection{Significance of the study}

Quality of housing delivery in any nation is a major index for measuring development and growth. Poor housing delivery in Nigeria has been a major concern from generation to generation. Finance constitutes a fundamental centerpiece in any real estate development and the ability of a developer to mobilize adequate funds for the project determines to a large extent the success of the development. Renaud (2004) opined that, where there is a well-structured housing finance system, the city appears well organized. Omirin (2007) asserted that, housing construction in Nigeria is incremental or progressive sometimes spanning over 15 years where adequate fund is not available. Finance therefore, is an all important factor in real estate development and a very critical ingredient to project no matter it nature. Thus, it is basically the fulcrum which sustains the lever for development (Ogedengbe \& Adesopo, 2003). Thus, there is need to assess capital market derivatives as viable source financing housing delivery.

\section{Literature review}

\subsection{Overview of Nigeria Real Estate Industry}

The Nigeria real estate industry may be described as one of the fastest growing sectors of the economy. Whilst it has been described as an unorganized and characterized by various factors that impeded organized dealings such as nonavailability of favorable priced long term bank financing, high interest rates and exorbitant transfer taxes, the real estate industry remains a major contributor to the Nigeria economy and the National Gross Domestic Product.

The two major drivers of the sector are the high population base and the state of the economy. With over 160 million people, Nigeria is the most populous nation in Africa. Its economies transformation over the few years has increased real GDP 
growth by an average of $6.7 \%$ per annum since 2006 . Nigeria is regarded as a frontier economy with strong potential for development and as such an increasing destination for capital, particularly in the service sector. Favourable demographic indices and economic growth make the country an attractive place for property investors, given that the demand for property is determined largely by economic development and demographic trends.

\subsection{The Housing Sector in Nigeria}

Rapid urban development has brought about dynamic changes in large cities in developing economies (Emoh, Oni \& Egolum, 2013). In sub-Saharan African (SSA), Nigeria is said to have the highest urban population that exceed most countries in Africa according to Buckley, Faulk \& Olajide (1994). As the population progress geometrically, the housing sector investment is not moving at the same pace. As noted by Sanusi (2003) that government investment in housing sector in the budgetary allocation is less than $3 \%$. While other emerging economies such as Thailand and Korea have $18 \%$ and $14 \%$ respectively, of their GDP as investment in housing (Saravanan, 2007).

Housing problems are multifarious and result from a complex interdependency of elements like material, political and socio-economic issues which interact with activities in other sectors of the economy (Okunsanya, 1994). However, Agboola \& Olatubara (2003); Windapo (2005) and Nubi (2005) are of the opinion that factors ranging from difficulty in land acquisition, lack of housing finance, high cost of building materials, problems on existing land policy to poor infrastructure (both physical and financial infrastructures) among other factor working against effective housing delivery in Nigeria. But, Nubi (2005) and Abdulai (2007) recognized finance for housing as the most important and complex factors dwindling people's aspiration to house ownership as land can be traditionally acquire to build a house. The construction however might be incremental and take a longer period to complete because of finance.

In Nigeria, public housing production agency effect is currently being felt in both the Federal and State governments domain but the informal sector has been active than the government agencies (Sanusi 2003; Nubi 2005; Nubi 2008). About $90 \%$ or more of the housing stock are traditionally provided by the private sector (Buckley et al, 1994; Ajanlekoko, 2001). However, Egbu (2007) noted that 54\% of residential accommodation is being provided by individual private property developers, $22.7 \%$ provided by corporate developers and $22.3 \%$ of residential accommodation is provided by government developers.

\subsection{The Nigerian Economy and Real Estate Sector: An Overview}

Nigeria achieved economic stability and growth in second half of 2010, with increased growth in the oil and non-oil sectors. Growth was attributed to increases in activities of the wholesale and retail trade sector and the Federal Government's amnesty development program for the Niger Delta, which fostered investment in the oil sector. Gross Domestic Product grew to $7.41 \%$ compared to $6.7 \%$ in 2009 while inflation remained at an average of $12 \%$ throughout the year; and Foreign Direct Investment (FDI) fell by 60\% from US\$6 billion in 2009 to \$2.3 billion in 2010 .

In 2010, activities on both the demand and the supply side in the real estate sector came to a standstill, overall growth of the sector stood at $10.48 \%$ in the second quarter of 2010 compared to $10.46 \%$ in the corresponding quarter of 2009 with marginal growth achieved as a result of activities in the low end of the market, characterized by small commercial and residential development. There was limited bank lending to major developers and investors, thereby stalling large scale high-end commercial and residential developments. For instance, in the high-end residential locations of Lagos 
(for example, Ikoyi and Banana Island), property values fell by as much as $40 \%$ and by up to $20 \%$ in the emerging middle income areas of Lekki. Property owners are presently willing to accept advance rent for one to two years compared with three years demanded during the property boom. The value of properties in the regeneration neighborhoods of the city continued to appreciate and it has increased by almost $10 \%$ by end of 2009. In the third quarter of 2010, the Federal Government embarked on several initiatives to encourage economic performance and improve investor confidence through the restructuring of the Nigerian Stock Exchange (NSE), enhancement of the quality financial institutions to restore depositors and investors' confidence in the financial system. Presently, credit flow for real estate developments has remained limited and new construction and infrastructure projects are almost nonexistent. However, as capital markets stabilize, there would be increased liquidity which would present additional drive for investing in emerging market real estate.

Regardless of these positive developments, the Nigerian economy is confronted by many serious challenges, which include structural imbalance and lack of diversification in the economy which excessively depend on oil revenue, high youth unemployment, poor infrastructure and widespread insecurity. Malize (2011) identified other challenges to include those fostered by the global economic meltdown that left capital markets impaired, in addition to crash in oil prices, the Niger Delta conflict, the Boko Haram insurgency, the fall of the exchange rate and stock market, which have all negatively impacted the real estate sector. Apart from these, the crisis in the banking sector in respect of which the Central Bank of Nigeria (CBN) injected N620 billion (USD 4 billion) in loans and support into nine banks and sacked eight executives for the aggregate non-performing loans that present further challenges for the real estate sector.

In recent time, the market is experiencing slump in demand at the high-end and yield is also dropping because investors with loan exposures on real estate investments are being forced to sell. Banks are no longer in the lending mode but in a 'recovery mode' to recover outstanding debt as a result of real estate financing that is being squeezed further due to limited purchasing power. It has now become very difficult for the investors to service their bank loans, and in so doing causing serious liquidity crisis for the banks and instability in the market. Consequently, banks are not eager to finance new projects, leading to excessive appreciations in property valuations in the region of 100 to $300 \%$. However, the demand drive factors play in the market have become ineffective as liquidity in the market arena dried up, and purchasing power of investors turned on a downward trend with less money in circulation (African Economic Outlook, 2011).

\subsection{The Nigerian Housing Market}

The Nigerian housing market full potentials seems to be untapped and undeveloped despite lot of opportunities that abound in the sector. This is basically due to many reasons amongst which include: lack of finance; government policy; lack of infrastructural development and high level of poverty. There is continuous increase in the average price of houses due to increase cost of building materials and inflation in the economy. This has concomitantly, contributed to upward trend in house prices which has significantly affected the number of units of houses constructed annually. The government efforts at addressing the problems have not been successful due to its unsustainable approach of providing houses to the people (Gbadeyan, 2011). These houses are grossly inadequate and unaffordable by the larger proportion of the masses for which they are meant for. There are efforts by the private individuals to help in alleviating this housing problem. The bulk of the housing problem is prevalent in urban cities, but there are lots of unoccupied and dilapidated houses in the rural areas. This is due to migration of people from most of these rural areas to urban centers for 
greener pastures. Most individuals that are involved in property development build for their own use or are homeowners, while the few ones involved in building for commercial purposes, build shops and space to let for offices because of the high rental income accruing from such commercial properties. The residential developments in most cases are illegal, informal and untitled. This is due to long, undue delay of title registration and laxity in enforcing development control regulations by the official of the urban and regional planning department (Fasakin \& Ogunmakin, 2006). Private sector's contribution towards alleviating this housing problem has been in the forms of Individual efforts, Cooperative associations, corporate bodies, Estate Agents, Non-Governmental Organizations'/charity organizations and foreign investors. (Gbadeyan, 2011).

\subsection{Real Estate Capital Structure Theory}

Even though corporate capital structure is one of the most researched subjects in economics; little has been done in the field of real estate companies. There are, however, a few scholars whom have studied the subject (Gau \& Wang, 1990; Bradley et al., 1998; Capozza \& Sequin, 1999; Brounen \& Eichholtz, 2001; Brown \& Riddiough, 2003; Feng et al., 2007; Giambona et al., 2008), but unfortunately most cover the American market; and foremost Real Estate Investment Trusts (REITs), which are under somewhat different judicial conditions, and are taxed differently than ordinary real estate companies. An example of this would be what Howe and Shilling (1988) found that due to their tax exempt status, REITs should have a capital structure with minimal, or no, debt - an irrelevant finding to most Swedish and European real estate companies. An interesting discovery by Brown and Riddiough (2003), however, although related to REITs, is that due to the fact that the cost of financing through bonds increased drastically - and non-linear - for bonds with "junk-bond status"; firms on a pursuit of an ideal capital structure, should try to optimizing their debt structure to enable them to receive an investment grade rating and minimize their financing cost. They consequently found that public debt issuing REITs tend to cluster just above investment grade ratings (Brown \& Riddiough, 2003). They also suggested a linkage between REITs' average debt maturity and its lease structure, as the lease maturity structure is of great importance to real estate owners' future incomes and clearly a strategic operational decision. Giambona et al. (2008), on the other hand, suggest that this may not be the case: long-term commercial real estate leases usually contain some form of inflation protection, as well as a protection against escalading operating costs; while the matching of short-term leases and shortterm debt increases both the cost and the risk of re-financing; hence, minimizing the importance of matching maturities. They also suggest that factors that affect market interest rates and the ones that change the rent equilibrium differ, along with the fact that short-term leases also increase the option-value for the parties involved - adding to their previous notion (Giambona et al., 2008).

A non-REIT-related study is Gau and Wang (1990) whom have studied real estate transactions in Vancouver, Canada, and concluded that transaction-based debt levels for property companies are effected by: borrower's capital constraints, non-debt tax shields, the absolute cost of debt finance and the cost of financial distress (Gau \& Wang, 1990). Moreover, Brounen and Eichholtz (2001) studied the stock price reactions to announcements by European real estate companies to issue both debt and equity. Their study further fuels to the previous research in the field: an announcement of debt issuing is followed by a non-negative price reaction, although modest, and an announcement of equity is exceeded by a significant negative price reaction (Brounen \& Eichholtz, 2001). When comparing the different European countries, they find that companies subjected to higher corporate taxes receive a more 
significant negative price reaction when announcing the issuing of equity - in line with the previously mentioned trade-off theory (Brounen \& Eichholtz, 2001).

\section{Research Methods}

This study used a cross-sectional research design, which allowed the researcher to examine the impact of capital market derivatives on effective housing delivery in Nigeria using questionnaires. The nature of analysis used in this study both descriptive and analytical research design. Thus, the study uses primary data, a questionnaire to assess how the people perceive the performance of capital market derivatives in housing delivery in Nigeria market. The survey was carried out in Lagos mega-city. Samples represent the number of participants actually selected for this particular study. It may be difficult sampling every member of the population, therefore, from the entire population; a total of 150 respondents comprising 90 stock brokers and 60 developers were selected as the sample size in which the instrument of study was applied.

The choice of stock brokers and estate surveyors premised on the fact that the former serve as a major player in the capital market operations and understand the workings of the market, while the later serves as a professional in the housing industry and can provide a reliable and adequate information towards achieving the study`s objectives. The random sampling technique was adopted. A total of 147 questionnaires were returned, and valid for analysis. The analysis of data was done using the Statistical Package for Social Sciences (SPSS) IBM version 20.0.

The specification of a model is based on the available information relevant to the objectives of the study in question. Here, the predictors are capital market derivatives (bonds, REITS, property unit trust, and loan stock and debenture stocks and the dependent variable effective housing delivery in Lagos state. The model is stated below;

$\mathrm{EHD}=\mathrm{f}\{\mathrm{BND}, \mathrm{RTS}$, PUT,LDS $\}$

Such that;

$\mathrm{EHD}=\propto_{0}+\propto_{1} \mathrm{BND}+\propto_{2} \mathrm{RTS}+\propto_{3} \mathrm{PUT}+\propto_{4} \mathrm{LDS}+\mu$

Where:

EHD $=$ Effective Housing Delivery

$\mathrm{BND}=$ property bonds

RTS $=$ Real estate investment trusts

PUT $=$ Property unit trust

LDS $=$ loan \& debentures stocks

$\mathrm{E}=$ Error term

$\mu_{\mathrm{i}}=$ Parameter Estimates

\section{Data Presentation, analysis and interpretation}

\subsection{Demographic Characteristics of the Respondents}

The Table 1 describes the Frequency distribution of respondents by demographic status. 
Table 4.1 Summary of Frequency distribution of respondents by demographic status

Total $(\mathrm{N}=147, \%=100)$

\begin{tabular}{|l|l|l|}
\hline Variables & Frequency & Percentage (\%) \\
\hline Gender & & \\
\hline Male & 123 & 83.7 \\
\hline Female & 24 & $16 . .3$ \\
\hline Age & & \\
\hline below 21years & - & - \\
\hline $21-30$ years & 33 & 22.45 \\
\hline $31-40$ years & 79 & 53.74 \\
\hline $41-50$ years & 28 & 19.05 \\
\hline 51 years and above & 7 & 4.76 \\
\hline Marital Status & & \\
\hline Single & 21 & 14.3 \\
\hline Married & 117 & 79.6 \\
\hline Divorced & 5 & 3.4 \\
\hline Widowed & 4 & 2.7 \\
\hline & & \\
\hline Educational Status & & \\
\hline Secondary & 3 & 2 \\
\hline OND/HND & 21 & 14.3 \\
\hline B.Sc/B.Ed/BA & 70 & 47.6 \\
\hline M.Sc/M.Ed/MA/MBA & 51 & 34.7 \\
\hline Ph.D & 2 & 1.4 \\
\hline & Source: Field Survey, 2015. & \\
\hline & & \\
\hline
\end{tabular}

The results in the Table 4.1 show demographic characteristics of respondents to the study , there are more male respondents with $83.7 \%$ than female respondents with $16.3 \%$. It shows that more male practitioners in the real estate development are accessible and filled questionnaire. The age category shows that none of the respondents is below the age of 21 , indicating that more matured people were sampled in the study area. The age bracket 31-40 years covered over fifty percent of the total respondents, with $53.74 \%$ of the respondents in this aged usually categorized as youth; shows that more youths engaged in real estate business in the study area, this was followed by ages of 21-30 years and $41-50$ years with $22.45 \%$ and $19.05 \%$ of the respondents respectively. The remaining $4.76 \%$ of the respondents were aged 51 years and above. On the marital status, majority of the respondents were married with $79.6 \%$ of respondents, $14.3 \%$ were yet to be married while the remaining $6 \%$ were divorced and widowed. This showed that the respondents that filled these questionnaires spread across various strata of marital status. The educational status of respondents was in terms of their highest qualification as at the time of this study. High level of education was observed among the respondents with $47.6 \%$ were graduates, $34.7 \%$ of the respondents specified Masters Education. Respondents with technical education (OND/HND) were $14.3 \%$ and $2 \%$ were secondary school certificate holders.

\subsection{Analysis according to Objectives}

The Table 4.2 shows respondent's preference for the available sources of finance for housing development. The purpose of this is to observe their perception as to which of the sources have the highest preference in terms of ranking and possibly know why 
the option/source is preferred. The responses revealed $66.7 \%$ of the respondents ranked first position the capital market derivatives. Next to this is the pension funds source which represents $14.3 \%$ of the respondents. The third and fourth position is shared by commercial and mortgaged sources of funds. The fifth most preferred source of funds for housing development in Nigeria is Insurance companies while the least preferred $\left(6^{\text {th }}\right)$ is the funds from friends and family. Thus, majority of the respondents preferred capital market funds for housing delivery and it is only in the absent of viable capital market funds that they resolve to other sources.

Table 4.2 Preference of respondents to sources of finance for housing development

\begin{tabular}{|l|l|l|l|}
\hline Total $(\mathbf{N}=\mathbf{1 4 7}, \boldsymbol{\%}=\mathbf{1 0 0})$ & \multicolumn{2}{|l|}{ Rank } \\
\hline Sources of finance & Frequency & $\%$ & \\
\hline Commercial banks & $\mathbf{1 0}$ & $\mathbf{6 . 8}$ & $\mathbf{3 . 5}$ \\
\hline Mortgage finance institutions & $\mathbf{1 0}$ & $\mathbf{6 . 8}$ & $\mathbf{3 . 5}$ \\
\hline Insurance companies & $\mathbf{5}$ & $\mathbf{3 . 4}$ & $\mathbf{5}^{\text {th }}$ \\
\hline Capital market & $\mathbf{9 8}$ & $\mathbf{6 6 . 7}$ & $\mathbf{1}^{\text {st }}$ \\
\hline Family and friends & $\mathbf{3}$ & $\mathbf{2}$ & $\mathbf{6}^{\text {th }}$ \\
\hline Pension funds & $\mathbf{2 1}$ & $\mathbf{1 4 . 3}$ & $\mathbf{2}^{\text {nd }}$ \\
\hline
\end{tabular}

Source: Field Survey 2015

Table 4.3 Showing respondents` perception of statement relating capital market derivatives financing for real estate

\begin{tabular}{|c|c|c|c|c|c|c|c|c|c|c|c|c|}
\hline \multirow{2}{*}{$\begin{array}{l}\begin{array}{l}\text { Total } \\
(\mathrm{n}=147, \%= \\
100)\end{array} \\
\text { Statements }\end{array}$} & \multicolumn{2}{|c|}{$\begin{array}{l}\text { Strongly } \\
\text { agree }\end{array}$} & \multicolumn{2}{|c|}{ Agree } & \multicolumn{2}{|c|}{ Undecided } & \multicolumn{2}{|c|}{ Disagree } & \multicolumn{2}{|c|}{$\begin{array}{l}\text { Strongly } \\
\text { disagree }\end{array}$} & \multirow[t]{2}{*}{ Mean } & \multirow[t]{2}{*}{ Rank } \\
\hline & Freq & $\%$ & Freq & $\%$ & Freq & $\%$ & Freq & $\%$ & Freq & $\%$ & & \\
\hline $\begin{array}{l}\text { The existing } \\
\text { financing } \\
\text { option for } \\
\text { real estate is } \\
\text { adequate } \\
\text { and effective } \\
\text { in providing } \\
\text { affordable } \\
\text { housing in } \\
\text { Nigeria }\end{array}$ & 1 & 0.7 & 3 & 2.0 & 7 & 4.7 & 42 & 28.6 & 94 & 63.9 & 1.43 & $7^{\text {th }}$ \\
\hline $\begin{array}{l}\text { The current } \\
\text { situation of } \\
\text { the capital } \\
\text { market } \\
\text { products for } \\
\text { real estate } \\
\text { finance is } \\
\text { not } \\
\text { favourable } \\
\text { for housing } \\
\text { affordable } \\
\text { delivery }\end{array}$ & 45 & 30.6 & 65 & 44.2 & 7 & 4.8 & 18 & 12 & 12 & 8.2 & 4.23 & $5^{\text {th }}$ \\
\hline $\begin{array}{l}\text { Pension } \\
\text { funds if } \\
\text { properly } \\
\text { channel } \\
\text { through the } \\
\text { capital } \\
\text { market will } \\
\text { be a good } \\
\text { financing } \\
\text { option for } \\
\text { real estate } \\
\text { project }\end{array}$ & 34 & 23 & 105 & 71.4 & 2 & 1.4 & 3 & 2.0 & 3 & 2.0 & 4.48 & $4^{\text {th }}$ \\
\hline REIT and & 111 & 75.5 & 23 & 15.6 & 1 & 0.6 & 7 & 4.8 & 5 & 3.4 & 4.89 & $2^{\text {nd }}$ \\
\hline
\end{tabular}




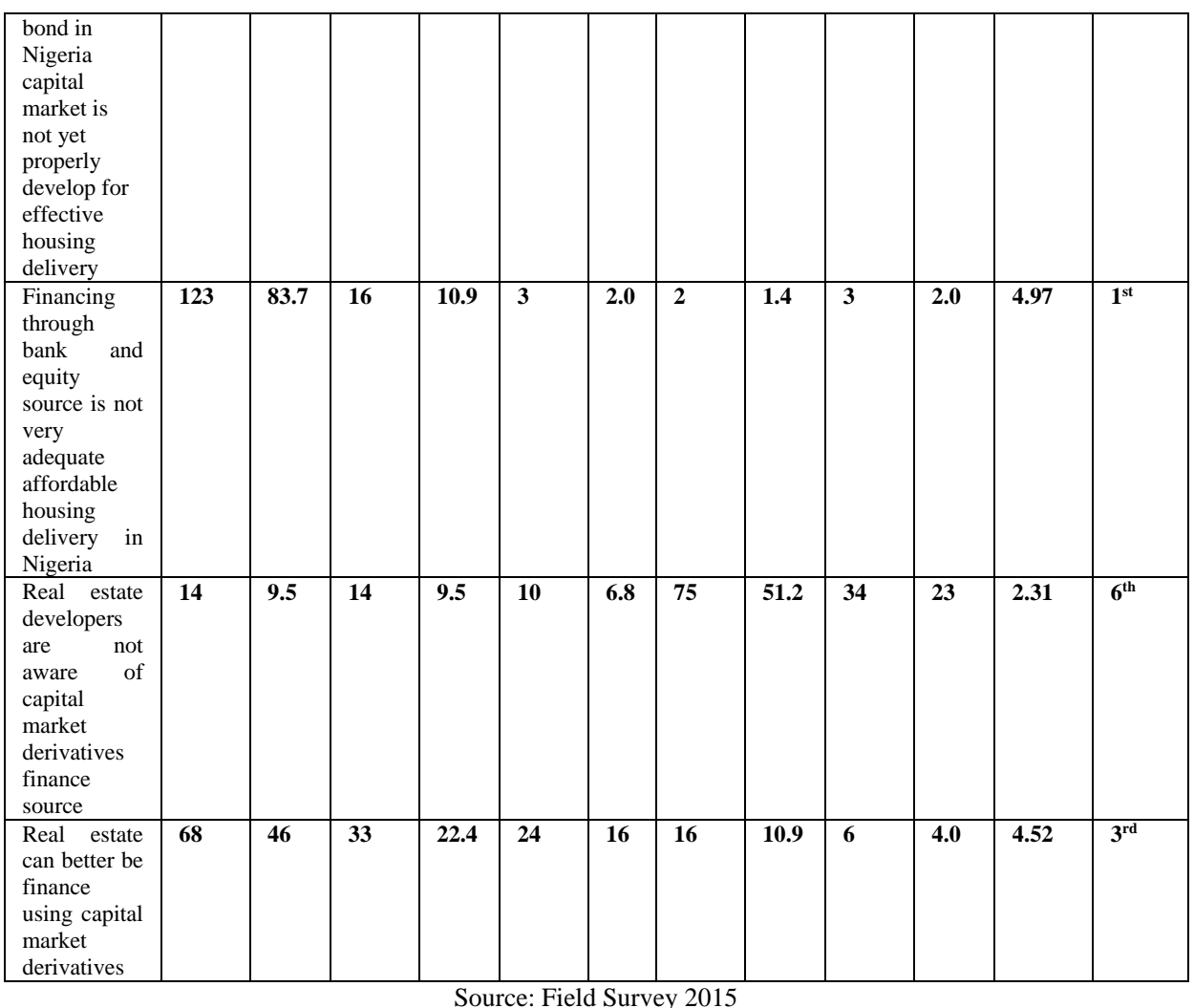

The Table 4.3 describes the perception of stockbrokers and real estate developers on capital market derivatives as it affects housing finance and the housing delivery. On whether financing through bank and equity source is not adequate for affordable housing delivery, the respondents agreed mostly with this statement, with $83.7 \%$ and $10.9 \%$ strongly agree and agree. This was also ranked $1^{\text {st }}$ among seven different statement used as proxy for capital market derivatives in housing delivery. This infers that respondent in the study area recognizes the fact that capital market derivatives can positively deliver adequate and affordable housing to the people. This will reduce the housing deficit problem in Nigeria.

The results also revealed that REIT and bond in Nigeria capital market is not yet properly develop for effective housing delivery; this is represented by respondents' responses of total of $91.1 \%$ that agree to this fact. This shows that despite the current situation of the market, if properly developed, these derivatives will make a great different in the housing finance market. This was ranked $2^{\text {nd }}$ which means that respondents recognized their importance most after the bank and equity.

In housing finance generally, the strategic position and advantage of financing through the capital market in the world over cannot be overestimated. In this study too, it was revealed that real estate can better be financed using capital market derivatives with responses of $46 \%$ and $22.4 \%$ respectively for strongly agreed and agreed position. This ranked $3^{\text {rd }}$ position.

This study seeks respondent opinion on pension fund in financing housing project. A good number supported funding of project through the medium but suggested that if properly channeled through the capital market it will be a good finance source towards adequate and affordable housing delivery in Lagos state. The responses revealed that majority of the respondent strongly agreed and agreed with $71.4 \%$ and $23 \%$ respectively. We can deduct from this that developers/investors will be ready to 
finance project using pension funds if there is a favorable arrangement for its usage. This also ranked $4^{\text {th }}$ in the hierarchy of the seven statement used as proxy for the variable tested.

Table 4.4 Correlations matrix of capital market derivatives and effective housing delivery

\begin{tabular}{|c|c|c|c|c|c|c|}
\hline & & $\begin{array}{l}\text { Effective } \\
\text { Housing } \\
\text { delivery }\end{array}$ & BND & RTS & PUT & LDS \\
\hline \multirow{3}{*}{$\begin{array}{l}\text { Effective } \\
\text { Housing } \\
\text { delivery }\end{array}$} & $\begin{array}{l}\text { Pearson } \\
\text { Correlation }\end{array}$ & 1 & $0.567^{* * *}$ & $.213^{* * *}$ & $.348^{* * *}$ & $0.486^{* *}$ \\
\hline & Sig. (2-tailed) & & .000 & .002 & .000 & .000 \\
\hline & $\mathrm{N}$ & 147 & 147 & 147 & 147 & 147 \\
\hline \multirow[t]{3}{*}{ BND } & $\begin{array}{l}\text { Pearson } \\
\text { Correlation }\end{array}$ & $0.567^{* *}$ & 1 & $.213^{* *}$ & $.348^{* * *}$ & $.486^{* *}$ \\
\hline & Sig. (2-tailed) & .000 & & .002 & .000 & .000 \\
\hline & $\mathrm{N}$ & 147 & 147 & 147 & 147 & 147 \\
\hline \multirow[t]{3}{*}{ RTS } & $\begin{array}{l}\text { Pearson } \\
\text { Correlation }\end{array}$ & $.213^{* * *}$ & $.213^{* *}$ & 1 & $.216^{* * *}$ & $.242^{* *}$ \\
\hline & Sig. (2-tailed) & .002 & .002 & & .002 & .001 \\
\hline & $\mathrm{N}$ & 147 & 147 & 147 & 147 & 147 \\
\hline \multirow[t]{3}{*}{ PUT } & $\begin{array}{l}\text { Pearson } \\
\text { Correlation }\end{array}$ & $.348^{* *}$ & $.348^{* *}$ & $.216^{* *}$ & 1 & $.351^{* *}$ \\
\hline & Sig. (2-tailed) & .000 & .000 & .002 & & .000 \\
\hline & $\mathrm{N}$ & 147 & 147 & 147 & 147 & 147 \\
\hline \multirow[t]{3}{*}{ LDS } & $\begin{array}{l}\text { Pearson } \\
\text { Correlation }\end{array}$ & $.486^{* *}$ & $.486^{* *}$ & $.242^{* *}$ & $.351^{* * *}$ & 1 \\
\hline & Sig. (2-tailed) & .000 & .000 & .001 & .000 & \\
\hline & $\mathrm{N}$ & 147 & 147 & 147 & 147 & 147 \\
\hline
\end{tabular}

**. Correlation is significant at the 0.01 level (2-tailed).

Table 4.4 shows the results for relationship between the variables (dependent and independent variables). The results established that there is moderate relationship between housing delivery and bond with $(\mathrm{r}=0.567, \mathrm{p}<0.01)$. In addition, all other independent variables also revealed positive relationship with effective housing delivery. Thus, the present of property bonds, real estate investment trusts, property unit trust, and loan and debentures stocks are essential for effective hosing delivery in Nigeria. It further shows that by their association, housing deficit could be reduced.

Table 4.5 Model Summary

\begin{tabular}{|c|c|c|c|c|c|c|c|c|c|c|}
\hline \multirow[b]{2}{*}{ Model } & \multirow[b]{2}{*}{$\mathrm{R}$} & \multirow[b]{2}{*}{$\begin{array}{c}\mathrm{R} \\
\text { Square }\end{array}$} & \multirow[b]{2}{*}{$\begin{array}{l}\text { Adjusted } \\
\text { R Square }\end{array}$} & \multirow{2}{*}{$\begin{array}{c}\text { Std. } \\
\text { Error of } \\
\text { the } \\
\text { Estimate }\end{array}$} & \multicolumn{5}{|c|}{ Change Statistics } & \multirow[b]{2}{*}{$\begin{array}{l}\text { Durbin- } \\
\text { Watson }\end{array}$} \\
\hline & & & & & $\begin{array}{c}\text { R Square } \\
\text { Change }\end{array}$ & F Change & df1 & $\mathrm{df} 2$ & $\begin{array}{l}\text { Sig. F } \\
\text { Change }\end{array}$ & \\
\hline 1 & $.753^{\mathrm{a}}$ & .567 & .549 & .80564 & .328 & 23.795 & 4 & 195 & .000 & 2.036 \\
\hline
\end{tabular}

a. Predictors: (Constant), BND, RTS, PUT, LDS

b. Dependent Variable: Effective Housing delivery 
Table 4.6 ANOVA

\begin{tabular}{|l|l|l|l|l|l|l|}
\hline \multicolumn{2}{|l|}{ Model } & $\begin{array}{l}\text { Sum of } \\
\text { Squares }\end{array}$ & Df & $\begin{array}{l}\text { Mean } \\
\text { Square }\end{array}$ & F & Sig. \\
\hline \multirow{2}{*}{1} & Regression & 61.777 & 4 & 15.444 & 23.795 & $.000^{\mathrm{a}}$ \\
\cline { 2 - 8 } & Residual & 126.566 & 195 & .649 & & \\
\cline { 2 - 8 } & Total & 188.343 & 199 & & & \\
\hline
\end{tabular}

a. Predictors: (Constant), BND, RTS, PUT, LDS

b. Dependent Variable: Effective Housing delivery

Table 4.7 Coefficients ${ }^{\mathrm{a}}$

\begin{tabular}{|c|c|c|c|c|c|c|}
\hline & & \multicolumn{2}{|c|}{$\begin{array}{l}\text { Unstandardized } \\
\text { Coefficients }\end{array}$} & \multirow{2}{*}{$\begin{array}{c}\text { Standardized } \\
\text { Coefficients }\end{array}$} & \multirow[b]{2}{*}{$\mathrm{T}$} & \multirow[b]{2}{*}{ Sig. } \\
\hline \multicolumn{2}{|c|}{ Model } & B & Std. Error & & & \\
\hline \multirow[t]{5}{*}{1} & (Constant) & 1.011 & .561 & & 1.802 & .073 \\
\hline & BND & .396 & .080 & .328 & 4.940 & .000 \\
\hline & RTS & .305 & .120 & .162 & 2.537 & .012 \\
\hline & PUT & .034 & .083 & .026 & .411 & .002 \\
\hline & LDS & .519 & .135 & .252 & 3.846 & .000 \\
\hline
\end{tabular}

a. Dependent Variable: Effective Housing delivery

The regression analysis results as shown in the model summary of Tables 4.5 indicates that there is positive relationship between capital market derivatives and housing delivery in Nigeria, with $r$ value 0.753 , showing strong positive relationship between the independent and dependent variable in the model. The table further revealed that $56.7 \%$ of the observed variations in housing delivery $\left(\mathrm{R}^{2}=.567\right)$ is explained by capital market derivatives. This means that, proper utilization of capital market derivatives will enhance and improve housing delivery in Nigeria. The analysis of variance (ANOVA) result in Table 4.6 shows that capital market derivatives had significant effect on effective housing delivery, $\quad(F=23.795, p<$ 0.01).The F-statistics which is used to measure the overall significance of the model. The probability of the F-statistics is less than 0.01 at $1 \%$.Durbin Watson gives a value of 2.036; which is not farther than the benchmark of 2. 0 , this implies that there is no serial correlation in the model. The Table 4.7 shows the rate change in the dependent variable that could be caused by the independent variables. From the results, property bonds, property unit trust and loan $\&$ debentures stocks can bring a significant change in the housing delivery in Nigeria which is all significant at 5\%. A unit increase in fund release for real estate development will increase housing delivery by $39.6 \%$ for property bonds; $3.4 \%$ for property unit trust and $51.9 \%$ for loan \& debentures stocks. Thus, proper injection of funds through this medium will enhance effectiveness of housing delivery in Nigeria.

The Table 4.8 represents the response of respondent for this study with respect to challenges hindering the use of capital markets derivatives for housing finance in the study area. The result also shows the mean and standard deviation of the distributions. A 5 point Likert format questionnaire of $1-5$ was adopted where 5 is ascribed to strongly agree and 1 to strongly disagree respectively. Most of the respondents agreed that there are a lot of challenges inhibiting the use of capital market derivatives for 
housing development in and this have drastically affected the available housing stocks and their quality.

Table 4.8 Descriptive statistics on the challenges hindering the use of capital market derivatives financing for housing project.

\begin{tabular}{|l|l|l|l|r|r|}
\hline \multicolumn{1}{|c|}{ Challenges } & N & Min & Max & Mean & $\begin{array}{l}\text { Standard } \\
\text { deviation }\end{array}$ \\
\hline Lack of awareness & 147 & 1.00 & 5.00 & 4.1237 & .84086 \\
\hline Size of investors firm & 147 & 1.00 & 5.00 & 4.4742 & 1.02890 \\
\hline Capital market policy. & 147 & 1.00 & 5.00 & 4.6186 & .76727 \\
\hline Lack of credit history & 147 & 1.00 & 5.00 & 4.6598 & .59674 \\
\hline $\begin{array}{l}\text { Inability of real estate developers firms to } \\
\text { provide acceptable collateral }\end{array}$ & 147 & 1.00 & 5.00 & 4.2137 & .74223 \\
\hline High interest rate risk & 147 & 1.00 & 5.00 & 4.4742 & .67526 \\
\hline Development risk & 147 & 1.00 & 5.00 & 4.3606 & .63229 \\
\hline Preference for Banks loan & 147 & 1.00 & 5.00 & 4.4596 & .63901 \\
\hline $\begin{array}{l}\text { Lack of the understanding of capital market } \\
\text { operation }\end{array}$ & 147 & 1.00 & 5.00 & 4.2143 & .64732 \\
\hline
\end{tabular}

Source, Field survey, 2015

Table 4.9 Measures needed to close the financial difficulty for Housing delivery

\begin{tabular}{|l|c|c|c|c|r|}
\hline MEASURES & $\mathbf{N}$ & Min & Max & Mean & $\begin{array}{r}\text { Standard } \\
\text { deviation }\end{array}$ \\
\hline $\begin{array}{l}\text { Establishing specialized lending institutions for } \\
\text { real estate firms }\end{array}$ & 147 & 2.00 & 5.00 & 3.9381 & .84086 \\
\hline $\begin{array}{l}\text { Putting ceilings on interest rates charged on } \\
\text { lending funds }\end{array}$ & 147 & 2.00 & 5.00 & 4.1237 & .76727 \\
\hline Subsidizing interest rates & 147 & 2.00 & 5.00 & 4.4742 & .59674 \\
\hline $\begin{array}{l}\text { Establishing special government-assisted- } \\
\text { financing schemes for real estate firms }\end{array}$ & 147 & 2.00 & 5.00 & 4.6186 & .67526 \\
\hline $\begin{array}{l}\text { Establish adequate legal framework and lending } \\
\text { policies within which lenders and borrowers can } \\
\text { effectively operate }\end{array}$ & 147 & 2.00 & 5.00 & 4.6598 & .74223 \\
\hline $\begin{array}{l}\text { Sharing the risk with other private financial } \\
\text { institutions through special arrangements }\end{array}$ & 147 & 2.00 & 5.00 & 4.3606 & 1.02890 \\
\hline $\begin{array}{l}\text { Awareness creation of the available derivatives in } \\
\text { the capital market for real estate financing }\end{array}$ & 147 & 2.00 & 5.00 & 4.4596 & .67221 \\
\hline
\end{tabular}

Source: Field study, 2015.

The Table 4.9 represents the response of respondent for this study with respect to measures needed to close the financial difficulty for housing delivery in the study area. The result also shows the mean and standard deviation of the distributions. Most of the respondents suggested various measures as presented in the table even as their mean cluster around positives agreements to the suggested measures but some few of the respondents still believe that Sharing the risk with other private financial institutions through special arrangements may never be a way out of the financial difficulty for housing development effective housing delivery.

\section{Conclusion and Recommendations}

This research effort has been able to empirically investigate the effectiveness of the capital market derivatives in housing delivery in Lagos state, Nigeria, with a view to identifying the challenges and proposing a workable means to improving the current 
situation. The study concluded that capital market and it derivatives in housing delivery is still at its early stage of development in Nigeria and the current situation of the market is not encouraging to make it a favorable finance source for housing development at a scale and affordable rate.

The housing industry and the capital market should accept the reality that there exists symbiotic relationship between available finance for housing and housing stocks. The value of ' $\mathrm{r}$ ' as calculated shows that there is a significant positive relationship between capital market derivatives and housing delivery in Nigeria. The study also recognizes the fact that developers of real estate are not adequately exploring the capital market using their derivatives for effective, adequate and affordable housing delivery and concluded that Nigerian capital market seems to be losing out since capital that is supposed to be invested in this laudable venture (real estate) is been tied down and used for other ventures that are not as profitable and secure as the housing project.

It can also be concluded as revealed by the study that so many challenges are hindering capital market derivatives from been used for housing finance and delivery in Nigeria ranging from policies to others factors and that awareness of the imperativeness and benefits of financing through the capital market is lacking even as this seem to be one of the major way to liberate people from their shackle of financial difficulty for real estate development, a synergetic effort between the market and developers is missing.

Housing supply in response to its demand remain a daunting challenge in Nigeria especially in the study area and finance has long been identified as one of the major issue hindering stocks delivery. Effective sources of housing finance are the only way to walk out of the cogwheel of this problem which the capital market seem to be a way out. From the above conclusion, the following recommendations were made:

(i) The capital market option should be considered by developers and investors in the housing market and be adequately explored since this can contribute over fifty percent of the required funds needed for housing delivery in any economy.

(ii) The capital market operators should channel funds into real estate development and investment to aid housing delivery in Nigeria.

(iii) A synergetic effort should be created between the capital market and real estate developers this will enhance effective housing delivery in Nigeria.

(iv) The policies of government on investment of capital market products and the condition required for borrowing should be made flexible and a bit liberal for real estate firms.

(v) An enabling environment also needs to be created for both the operators in the capitals market and the real estate developers to ensure optimum service delivery.

(vi) The real estate developers firms should also see it as a matter of importance to create or form alliance for them to be effective in their operation and to gain more recognition and trust as well as access to the capital market funds instead of the present finance sources.

(vii) An enlightenment programme is also required from the government and the capital market regulators on the available products/derivatives for housing finance in the market.

\section{References}

Abdulai, R.T. (2007). The operation of urban traditional landholding institutions in Sub-Saharan Africa: a Ghana study, Unpublished Ph. D Thesis, School of Engineering and the Built Environment, University of Wolverhampton, UK. 
Adedeji Y.M \& Olotuah, A.O. (2012). An evaluation of accessibility of low-income earners to housing finance in Nigeria American-Eurasian Journal of Scientific Research, 7 (1), 23-31.

Adejumo, A. (2008). Social housing in Nigeria - an imminent mass housing revolution? Retrieved on May 18, 2014 from http://www.nigerianmuse.com/2008110114261325/articles/social-housing- inNigeria-an-imminent-mass-housing-revolution.

African Economic Outlook (2011). available at http://www.africaneconomicoutlook.org/en/countries/west-africa/nigeria/, accessed May 12, 2014.

Agboola, T. \& Olatubara, C.O. (2003). Private sector driven housing delivery in Nigeria: issues, constraints, challenges and prospects, Paper presented at National Workshop organized by the Dept of Estate Management, University of Lagos in collaboration with the Real Estate Development Association of Nigeria, University of Lagos.

Ajanlekoko, J. S. (2001). Sustainable housing development in Nigeria-the financial and infrastructural implication, Paper presented at the International Conference on Spatial Information for Sustainable Development, 2nd-5th October, 2001, Nairobi-Kenya

Alhashimi, H. \& Dwyer, W. (2004). Is there such an entity as a housing market? Paper presented at the 10th Annual Pacific Rim Real Estate Conference Bangkok, Jan. 2004

Berggren, B. \& Silver, L. (2011). Financial systems, actors, and risk management, lecture April 11th 2011, Royal Institute of Technology, Stockholm

Boonyabancha, S. (2002). The role of housing finance in achieving adequate shelter for all. In financing Adequate Shelter for All UNCHS, Nairobi.

Buckley, R.M., Faulk, D. \& Olajide, L. (1994). Private sector participants, structural adjustment and Nigeria's new National housing policy: Lessons from foreign experience, Journal of African Economics, (3) 2387-2411.

Emoh, F.I \& Nwachukwu, C.C. (2011). Critical Issues in real Estate finance as an index in building construction project management success in Nigeria. American Journal of Social and management science, (2)1, 76-90.

Egbu, A. (2007). The impact of land use planning on urban land markets in subSaharan Africa: A case study of Nigeria. Unpublished PhD Thesis, School of Engineering and the Built Environment, University of Wolverhampton, Wolverhampton- United Kingdom.

Ewah, S.O.E., Esang, A.E. \& Bassey, J. U. (2009). Appraisal of capital market efficiency on economic growth in Nigeria. International Journal of Business and Management, December, 219-225.

Folorunsho, C.O; Khan, T.A \& Olowoyo, S.A. (2012). Trends, realities and prospect of housing delivery through mortgage financing in Nigeria British Journal of Arts and Social Sciences 2 (7), 21-34.

Kim, K. H (1997). Housing finance and urban infrastructure finance, Urban Studies 10(34), 1597-1620.

Mabogunje, A. L. (1989). The development process: A spatial perspective (2nd edition), London: Unwin Hyman.

Mary, J; Samson, A.; A \& Akpeki, O. E (2012). Capital market as a veritable source of development on Nigeria economy. Journal of Accounting and Taxation, $1(4), 7-18$.

Nevova, T. (2010). Expanding housing finance to the underserved in South Asiamarket review and forward agenda. International Bank for reconstruction/ World Bank. 
Nubi, T.O. (2008). Affordable Housing delivery in Nigeria, Paper presented at the Southern African housing foundation international conference and Exhibition, 12 - 15 October 2008 - Cape Town, South Africa.

Nubi, T.O. (2005). Housing finance in Nigeria- need for Re-engineering (Unpublished Reports)-www.housingfinance.org/pdfstorage/Africa retrieved March 2014.

Nyong M.O. (1998). Capital market development and long run economic growth: Theory, Evidence and Analysis, First Bank Review, December, 13-38.

Ogedengbe, P. S \& Adesopo, A.A (2003). Problem of financing real estate development in Nigeria, Journal of humanity and Ecology, 14 (6), 425-431.

Ojo, A. O. (2009). The role of secondary mortgage facility in expanding the availability of funds for mortgage finance in Nigeria. Unpublished M. Sc. thesis submitted to the department of Real Estate and Construction Management, Royal Institute of Technology (KTH), Sweden.

Okunsanya, O. (1994). Strategies for cost efficient housing delivery in Nigeria's Urban centre, Journal of the Federation of Building and Civil Engineering Contractors in Nigeria, 10(3), 4 - 8.

Omirin, M. M. \& Nubi, T. O. (2007). The role of primary mortgage institutions in housing Delivery, Housing Finance International, 2(5), 52- 56.

Onokwube, H.N (2007) The role of capital market and other Sources of Funds in Private Sector Housing Development In Private Sector Driven Housing Delivery: Issues, Challenges and Prospects edited by Nubi, T.O; Omirin, M.M \& Afolayan, A. S, published by Estate Management Department University of Lagos, Akoka, Nigeria.

Osaze, B.E. (2000). The Nigeria capital market in the African and global financial System. Benin City: Bofic Consults Group Limited.

Oyejide T A (1994). The financial system and economic growth in the context of political transition. Central Bank of Nigeria Economic and Financial Review, 32(3), 260-267.

Poole, W. (2003). Housing in the macro economy, Federal Reserve Bank of St Louis May/June 2003, 1-8.

Quigley, J. (2000). A decent home: housing policy in perspective, Brooking Papers on Urban Affairs, 1(1), 53-99.

Renaud, B. M (2004). Mortgage finance in Emerging Market: Constraints on feasible development paths, paper presented at USC FBE/LUSK Real Estate Seminar.

Sanusi, J.O. (2003). Mortgage finance in Nigeria: issues and challenges, Paper presented at the 9th John Ekpenyong Memorial Lecture organised by NIESV, 29th January.

Saravanan, P. (2007). Recent experiences in the housing finance sector - A study with reference to India, Housing Finance International

Sule, O. K. \& Momoh, O. C (2009). The impact of stock market earnings on Nigeria per Capita income. African Journal of Accounting, Economics, Finance andBanking Research, 5(5), 77-89.

Tibaijuku, A.K (2002). "Foreword" In financing adequate shelter for all UNCHS, Nairobi.

Torty, D. (2002). Investing in the Nigerian capital market and privatization programme, FGBMFI Awka Zone Seminar/Workshop on Christian Business Network, June. 2002.

Windapo, A. (2005). A study of factors determining housing needs, demand and supply for improved housing in selected Nigerian cities. Unpublished $\mathrm{PhD}$ Thesis, University of Lagos, Lagos - Nigeria. 
Yinka, K. (2011). Intervention funding. A must for affordable housing in Nigeria finance. Internet Publication's Retrieved March 62014. 